\title{
PEDAGÓGUSSZEREP A TEHETSÉGFEJLESZTÉSBEN
}

Szerző:

Koncz István

Professzorok az Európai Magyarországért

Egyesület

\section{Lektorok:}

Demetrovics János

Eötvös Lóránd Tudományegyetem

Sarka Ferenc

Magyar Tehetséggondozó Társaság

Varga Imre

Szegedi Tudományegyetem

Mező Ferenc

Debreceni Egyetem
Szerző e-mail címe:

fittego@gmail.com
Koncz I. (2015): Pedagógusszerep a tehetségfejlesztésben. Különleges Bánásmód, I. évf. 2015/4. szám, 5-19. DOI 10.18458/KB.2015.4.5

\begin{abstract}
Absztrakt
A tanulmány a tehetségesekkel foglalkozó pedagógusokra fókuszál. Központi kérdései: Milyen jellemzöi vannak e pedagógusoknak? Hogyan lehet diagnosztizálni ezeket a jellemzöket? Fejleszthetök-e ezek a jellemzők? Milyen speciális szerepe van a pedagügusoknak a tehetségazonosításban és -fejlesztésben? E kérdések már több évtizede állnak a tehetség pedagógia középpontjában, s most e tanulmány egy lehetséges választ ad rájuk.
\end{abstract}

Kulcsszavak: tehetség, tanár

Diszciplina: pszichológia, pedagógia

\section{Abstract \\ TEACHERS' ROLE IN THE TALENT DEVELOPMENT}

This study focuses on teachers who work with gifted and talented students. Its central questions are: What are the distinctive characteristics of these teachers? How can we diagnose these characteristics? Can we develop these characteristics? What special roles have the teachers in case of talent identification and development? These questions have been in the centre attention of talent education for more decades, and now, this paper gives a possible answer.

Keywords: talent, teacher

Disciplines: psychology, pedagogy 


\section{A sikert garantáló személyiségjegyek a pedagógusi tevékenységben}

Vajon a jó tanárnak milyen tulajdonságokkal kell legalább erős átlagon, vagy magas értéken rendelkeznie, s melyek a sikert hozó tulajdonságok? Egyes kutatók leggyakrabban a kezdeményezőkészséget, a nyíltságot, a humort, a lelkesedést, az önbizalmat és a barátságot nevezték meg. Mások a csatlakozó képességet, a kezdeményező képességet, a kitartást, a szervezőképességet, az alkalmazkodóképességet és a beszédkészséget preferálják. Ismert tény, hogy a gyakorló szakembert is mindig csak „,mezőben”, környezetében lehet tanulmányozni, ez is indokolhatja a profil- és térképkészítés igényét.

Ha valaki elgondolkodik azon, hogy vajon rendelkezik-e a sikert hozó tulajdonságokkal, akkor érdemes elöször tesztek felhasználásával személyiségtérképet, majd én-dinamikai térképet készíteni önmagáról.

E vizsgálatok eredményei jelzik a tanár számára a kihívások kezeléséhez, a kiegyensúlyozott életvitelhez, a sikeres pedagógiai munkához szükséges személyiségjellemzők szintjét és állapotát. Megmutatják, hogy az egyén mennyire elővigyázatos, mennyire önzetlen és toleráns, milyen az önismerete és az emberismerete, mekkora autonómiával, önbizalommal, kockázatvállalási képességgel, teherbírással, becsvággyal és függetlenségi vággyal rendelkezik, stb. (Koncz, 2006).

A személyiségjegyek fejlesztése szempontjából tudnunk kell, hogy azok az ismertetőjegyek edzhetők leginkább, amelyek nem mélyen horgonyoznak a személyiségben. Például a magabiztosság éppen ezért nehezebben változtatható, mint például a tolerancia, vagy az elővigyázatosság. Az emberismeret viszont megtanulható, ezzel szemben mindazok a jegyek (pl. optimizmus, becsvágy, függetlenség stb.) nehezen edzhetők, melyek a múltban gyökerező lelki alapmagatartás elemei.

Egy ilyen térkép középpontjában az összehangolt önismeret, reális önértékelés, s a flexibilis önreflexió áll. A tanár nem lesz sikeres például akkor, ha közelítőleg sem tudja bemérni saját kommunikációs képességeit, s nem tudja megérteni azt, hogy milyen hatást vált ki a neveltjeiböl.

Az összehangolt önismeret alapelemei a következők:

- magabiztosság, önbecsülés,

- kiegyensúlyozottság,

- gátlásmentes személyiségközvetítés,

- becsvágy, akaraterő,
- önkontroll, belsö kontrolosság,

- szorongásmentesség,

- kezelési képesség, kudarctürés,

- az én-konfliktus kezelése.

A jó pedagógus tanítványai körében a biztonság adásával válik kiszámíthatóvá. Ennek alapelemei (Koncz, 2008):

- hiteles pálya- és szakismeret,

- személyes példa és minta,

- problémastrukturáló képesség,

- tanuló- és feladatorientáltság,

- kedvező lelki klímahangulatot teremtő képesség,

- sikerorientáltság,

- optimizmus,

- teljesítmény centrikusság,

- biztos nevelési folyamat-vezérlés,

- jó szándékok, pozitív érzések éreztetése,

- nyugalom és erő sugárzása.

$\mathrm{Az}$ eredményes pedagógus, jellemzője az erősen átlagos vagy erős elkötelezettség, elhivatottság, melynek alappillérei: büszkeség, bizalom, az eredmény iránti felelősség, részesülés a sikerben és annak közkinccsé tételében, az iskolához, intézményhez való tartozás büszke érzése, kompetencia az adott szakterületen, felelősség az eredményekért. 
A jó pedagógus (természetes) alapvető vágya, hogy hatékony legyen környezete és önmaga kialakításában, irányításában.

Végezetül a pedagógia területén, különösen a fejlesztő tevékenységben sem kívánatosak a munkát akadályozó, főbb negatív személyiségjellemzőkkel bíró egyének. E területen sem lehet szerencsés: a szkizoid, a kényszeres, a paranoid, nárcisztikus személyiségek nevelöi feladatokkal való megbízása.

\section{A tanár személyisége és tulajdonságai, tanári személyiségvizsgálat}

Az iskolai környezetben a gyermek fejlődését befolyásoló tényezők elsődleges forrása maga a tanár. A tanárok személyiségének kutatása soha nem volt olyan kiterjedt és szisztematikus, mint a gyermek pszichológiai jellemzőinek vizsgálata, van azonban néhány témakör, amivel Fontana (1991) és a szerző összefoglalásában érdemes foglalkozni.

A tanári személyiség és hatékonyság egyik legkiterjedtebb vizsgálatát Ryans vezette le 1960ban az Egyesült Államokban. Ryans (1960) szerkesztett egy speciális értékelő skálát, aminek segítségével azt találta, hogy a sikeres tanárok melegszivüek, megértöek, barátságosak, megbizhatók, rendszeresek, jó a képzelöerejük és lelkesek. Azt is megfigyelte, hogy a felsorolt tulajdonságok jelentősége csökken, ahogy a tanított gyerekek életkora nő, tehát minél idősebb egy diák, annál könnyebben képes alkalmazkodni tanárához, a nevelö hiányosságaihoz.

Az sem lehetetlen, hogy léteznek egyéb személyiség-változók, melyek kompenzálják a Ryans által mért tulajdonságok hiányosságait. Rosenshine (1970) kutatásának eredményei szerint ilyen változó lehet a gyermekekkel szembeni elfogadó viszonyulás. A tanár által gyakran kritizált diák (föleg, ha már amúgy is alacsony az önértékelése) elveszti a képességeibe vetett maradék bizalmát is, és hajlamos alulteljesíteni. Így az a tanár, aki nyomásgyakorlással akarja a gyerekeket magasabb teljesítményre szorítani, hosszú távon sokat árthat az érzékenyebb diákok lelki fejlődésének.

A kutatásokból az kiderült, hogy a sikeres nevelők kevésbé elfogadott kollégáikhoz képest több időt töltenek az órákra való felkészüléssel, a gyerekekkel több iskolán kívüli aktivitásban vesznek részt, és jobban érdekli őket a diákjaik egyénisége. Ez azonban nem jelenti azt, hogy erős érzelmi szálakkal kötődnek diákjaikhoz. Természetesen jó, ha egy tanár kedveli az oktatott gyerekeket, de mindig meg kell őrizni velük szemben felelősségtudatát és szakmai objektivitását.

\section{További kutatások üzenete}

A tanítás során igen sokféle diákkal, igen sok helyzetben kerül kapcsolatba a tanár. Nyilvánvalóan nincs egyetlen, minden helyzetre alkalmazható tulajdonságsor, illetve magatartásminta, mely általánosan eredményes minden diák és tanulási helyzetben. A jó tanárok olyan emberek, akik több területen is képesek színvonalas teljesítményt nyújtani - olvashatjuk a OECD 2005-ös összegzésében.

Továbbá rendszeresen előforduló megállapítás, hogy az eredményes tanár jó szellemi képességekkel és komoly tudással bír, rendezett életmódja van, és strukturáltan gondolkodik, kommunikál és tervez. A diákok jobban teljesítenek olyan tanárok mellett, akik jól teljesítenek írásbeliséget és verbális képességeket mérő teszteken (Gustafsson, 2003).

Lineáris összefüggés állapítható meg a tanárok elméleti képesítése és diákjaik teljesítménye között. A hatás természettudományi tárgyakban egyértelmübb, mint a matematikában. Másrész- 
ről viszont egy USA-ban készült tanulmány (Goldhaber and Brewer, 2000) ugyan pozitív összefüggést talált a tanárok diplomája és a matematikatanítás eredményessége között, de nem talált hasonló egyértelmü összefüggést a természettudományi tárgyak vonatkozásában.

Wilson, Floden, és Ferrini-Mundy (2001) tanulmánya pozitív összefüggést talált a tanárok szaktárgyi felkészültsége és diákjaik teljesítménye között, de megjegyezték, hogy a tárgyakkal kapcsolatos ismeretek fokozása egy adott szint fölött nem javítja az eredményt. Arra a következtetésre jutottak, hogy van egy küszöbérték a tárgyismeretben, ami szükséges az eredményes tanításhoz, de annál magasabb - legalábbis az akadémiai képesítésekkel mérhető - szint nem okvetlenül fokozza a diákok tudását. Ez az állítás alátámasztja Monk (1994) eredményét, aki szerint a tanárnak a tárgy óráin felmutatott szaktárgyi felkészültsége pozitív összefüggésben áll a diákok természettudományi tárgyakban felmutatott teljesítményével; az összefüggés fordított értelemben tűnik lineárisnak, azaz egy adott szint fölötti szaktudáshoz csökkenő diákteljesítmény értékek tartoznak.

Az itthoni kutatások (Bábosik, Koncz, Kozma) elsősorban pedagógusi-pedagógiai kompetencia összerendezett meglétéhez, a tanár mintakövető szerepéhez, s biztonságot sugárzó személyisé-géhez kötik a tanár sikerességét, de nagy a jelentősége a differenciált bánásmód ismeretének is.

A fentiekből kiderül, hogy a ,jó” tanár legfontosabb jellemzője a rugalmasság: a képesség, hogy módszereit a helyzet (tantárgy stb.) követelményeihez és a diákok igényeihez tudja igazítani. Az a tanár, aki túl merev és tántoríthatatlanul hiszi, hogy az ő módszerei az egyedül célravezetők, diákjait és önmagát is számos értékes tanulási tapasztalattól, lehetőségtől fosztja meg. A legtöbb nevelö azonban szerencsére nyitottan viszonyul az új ötletekhez, és még, ha gyanúsnak is tünik egyik-másik, mindig érdemesnek tartja legalább egyszer kipróbálni azokat. Az oktatásban - akárcsak a pszichológiában - nem létezik „,végső igazság”.

A tanítás-fejlesztés sikeréhez a pedagógusoknak alapvető ismeretekkel kell rendelkezni $a$ serdülö és ifjúkor jellemzőiröl, s a tanulók személyiségbeli sajátosságairól. E körben alapmünek számít dr. Ranschburg Jenő „A serdülőkor” címü írása (Ranschburg, 2013), s hasonlóan Mönks és Knoers (2004) „Fejlődéslélektan” címü munkája. A sikeres tanári kommunikáció motívumait dr. Berentés Éva a „Sarokpontok”-ban megjelent írásából lehet nyomon követni. A serdülök önismeretének elméleti és gyakorlati vonatkozásait dr. Koncz István „Kamaszkapaszkodó” címü müvéből lehet elsajátítani (Koncz, 2005). A 10-18 éves tanulók önismereti jellemzőit dr. Koncz István és dr. Kovács József (2011) „Önismereti sarokpontok” címü müvéből ismerhetik meg.

Ugyancsak alapmű dr. Tóth László (2000) „Pszichológia a tanításban” címü könyve.

A nélkülözhetetlen elméleti felkészülés után a pszichológiai csoportmunka vezetésére kell gyakorlati ismereteket adni a tanároknak. Ehhez hasznos segítséget dr. Bagdy Emőke és dr. Bugán Antal írásai és a szerző adnak.

A siker érdekében a tanárok számára speciális felkészítés is szükséges. Ennek keretében elsősorban a tanulók személyiségdimenziói, szociális extroverziói mérésére, a tanulási stílusok feltérképezésére és - a hatékonyság érdekében szükséges - javítására, az önelfogadás mértékének növelésére, a kudarcok feldolgozási módjainak tudatos alkalmazására, az empátia - labor müködtetésére, a pozitív pszichológiai légkör megteremtésére és karbantartására kell felkészíteni a pedagógusokat. A speciális felkészítés csoporttechnikákkal, intenzíven történhet. (A tanulók megismerésének technikáit Daróczy Sándor és Koncz István Szocio-pedagógiai analizis és fejlesztö technikák I-II. címü írásából ismerhetik meg - Daróczy és Koncz, 2002). 


\section{A tehetségek gondozásához szükséges nevelői attitüdök, tanári személyiségjegyek}

A továbbiakban azt vizsgáljuk meg, hogy - kutatók szerint - milyen legyen a tehetséges tanulókkal foglalkozó pedagógusok személyisége, vagyis melyek a tanárok elvárható, szükséges tulajdonságai, személyiségjegyei. Ehhez nézzük át Cropley és McLeold (1986) a következőkről szóló 1986-os összefoglalóját:

Maker (1975) a következő személyiségjegyeket gyüjtötte össze: magas intelligencia, rugalmas-ság, kreativitás, magabiztosság, széles érdeklődési kör, humorérzék, igazságosság, határozottság, türelem, nyitottság a tanulmányi (academic) szempontból kivételes gyerekekre és a velük való együttmüködésre, önismeret, hajlandóság az extra idő- és erőráfordításra, lelkesedés mind a tanulás, mind a tanítás iránt, hajlandóság arra, hogy inkább támogató legyen és ne irányító. Maker később két alapvető jellemvonásra redukálta a listáját: képesség a tehetséges gyermekkel való kapcsolatteremtésre és nyitottság a változás iránt.

Feldhusen (1984) a témával kapcsolatban jó néhány évre visszamenőleg feldolgozta a vonatkozó publikációkat a tehetséges gyermekek tanáraira vonatkozóan. Írását érdemes elolvasni!

Bishop (1975) empirikus vizsgálatában nagyító alá vette a tehetséges gyermekek sikeres tanárait, majd a kérdőívek és interjúk segítségével összevetette őket az átlagos tanárokkal.

Az eredmények azt mutatták, hogy a fent említett jellemvonások tekintetében szignifikáns különbség van a tehetséges gyermekek tanárai és a felméréshez véletlenszerüen kiválasztott „rendes” tanárok között, vagyis nem pusztán „anyáskodó” vonásokról van szó.

Erre a sejtésre Hultgren és Seeley (1982) tanulmánya ad választ, miszerint mikor több száz szakértőnek és gyakorló tanárnak azt a kérdést tették fel, hogy a 24 megkívánt feltétel közül melyekkel kell rendelkeznie a tehetséges gyermekeket tanító tanárnak, akkor ezek mindegyikében teljes volt az egyetértés.

Silverman (1982) empirikus alapokon nyugvó tanulmánya viszont sokkal megnyugtatóbb eredményt hozott. Ö tapasztalt és sikeres tanárokat figyelt meg tanítási órák alatt, és megfigyeléseit összehasonlította a „rendes” tanároknál tapasztaltakkal, akiket szintén munkájuk közben tanulmányozott. Vizsgálatai azt bizonyítják, hogy a tehetséges gyermekek tanárai, az úgynevezett „,mester” tanárok az önálló tanulással kapcsolatos szokások elmélyítését segítették elő: megpróbálták elkerülni a „szájbarágós” módszert és arra bátorították a diákokat, hogy saját maguk jöjjenek rá a dolgokra. Provokatív és divergens kérdéseket tettek fel, melyekre érvekkel kell válaszolni. Arra buzdították a diákokat, hogy önállóan döntsenek és értékeljék önmagukat. Az úgynevezett „mester” tanárok másik szembetünő vonása az volt, hogy sokkal közelebbi kapcsolatot tudtak teremteni diákjaikkal, nemcsak meghallgatták öket, bekapcsolódtak a tanulási folyamatba és a problémamegoldásba, hanem mind óra előtt, mind óra után még bizonyos időt is együtt töltötte a diákjaikkal.

Az az elképzelés, hogy a tehetséges gyermekek tanításához speciális jártasságokra van szükség, magában rejti azt a problémát, hogy vannak olyan dolgok, amelyet a tehetséges gyermekek tanárai meg tudnak tenni, viszont azok a tanárok, akik nincsenek speciálisan kiképezve, ezeket vagy nem tudják, vagy nem akarják megtenni.

Denton (1984) az azonosítással foglalkozik részletesebben. Azt mondja, hogy általában a tanárok fel tudják ismerni a tehetséges gyermekeket, különösen akkor, amikor a tehetség nem globálisan, hanem konkrét mivoltában jelentkezik.

A tehetséges gyerekek felismeréséhez a tanároknak rendelkeznie kell azzal a képességgel is, hogy provokáljanak, stimuláljanak, érdeklődést és kíváncsiságot keltsenek (Kerry, 1983). Ezzel kapcsolatban felmerül az a kérdés, hogy mit tesznek a tehetséges gyermekek tanárai, ami 
megkülönbözteti őket a „rendes” tanároktól. A „mester” - tanárok arra ösztönözték diákjaikat, hogy hozakodjanak elő a saját ötleteikkel, elfogadták az ilyen ötleteket, valamint arra késztették őket, hogy értékeljék az oktatásukat. Odafigyeltek a választás módjára, ezzel azt segítve elő, hogy ne a gondolkodási folyamat végére, hanem a problémamegoldásra koncentráljanak. Sok időt töltöttek el a gyerekekkel az iskolán kívül is és gyakran közös tanulásba is fogtak velük.

Ezek a vonások újszerü rálátást adnak a kreativitást támogató tanár jellemzőire. Annak ellenére, hogy nem szabad figyelmen kívül hagyni az „anyai” gondoskodásra utaló állításokat sem, mégis ez a megközelítés konkrétabb képet ad a tanári magatartás speciális jellemzőiröl. Ezek Balogh, Bóta és Dávid (1999) szerint:

- nyitott, elfogadó attitüd (85\%)

- kreatív (80)

- nagy tárgyi tudás $(78 \%)$

- motiváló képesség $(75 \%)$

- jó humor $(72 \%)$

- ambiciózus (64\%)

- alkalmazkodni tud a diák igényeihez (54\%)

- empatikus (48\%)

- önkritikus $(44 \%)$

Sisk (1975) a sikeres tanári munka feltételeinek tatja az alábbi jártasságokat:

1. jártasság a tanári diagnosztikában,

2. jártasság az irányításban és a vita levezetésében,

3. jártasság a tanulási tapasztalatok megtervezésében, beleértve a kognitív müködés minden szintjét,

4. jártasság a szükséges érzelmi feltételek megteremtésében (pl. motiváció, magabiztosság, stb.)

Mulhern és Ward (1983) különbséget tettek a tanárok személyes és professzionális jellemvonásai között:

Személyes jellemvonások (a felvételihez): $\quad$ Professzionális jellemvonások (a program

- intellektuális képességek

- interperszonális képességek

- sikerorientáltság

- stabil személyiség

- intellektuális kíváncsiság

- szervezésre való képesség

- vezetésre való képesség során kialakítandók):

- tárgyi tudás

- információ kezelésének a képessége

- tanítási képességek

- diagnosztikai jártasság

- a programok tanításában való jártasság

- programfejlesztési képességek

- programvezetői képesség

Összegezve a tehetségfejlesztö tanár személyiségéröl mondottakat:

- Rendelkeznek a minden tanárra jellemző vonásokkal;

- Rendelkezniük kell speciális vonásokkal, illetve másoknál dominánsabban megjelenő általános jellemzőkkel; 
- Amellett, hogy a saját tudományterületeiken „mesteri” szinten állnak, magas szintü tanulásra való felkészültség, erős kompetencia kell, s ezen kívül - miközben pozitív attitüdöt alakítanak ki a speciális képességekkel rendelkezők irányában, s biztonságot adó légkört tartanak fenn - képesek speciális ellátást biztosítani a tehetség optimumig történő kibontakozásához.

A tehetséges gyerekek tanárait speciális kihívások (is) érik, ezért speciális személyiségjegyek és készségek is szükségesek munkájukhoz. Nézzük meg, hogy a tanári szerepek mellett milyen „finomságok” lelhetők fel a szakirodalomban.

A tehetségfejlesztő pedagógus különös szerepét számos szakkifejezés jelzi. Például facilitátor (Rogers), mentor, forrás-tanár, sámán, lelkész, misztikus gyógyító (Adelson), a kockáztató (Viscott), az önkifejezés-gazdagító (Zsolnai J.), a (teljesítmény) motivációfelelös, a devianciatoló, a diagnosztika, a prognosztizáló, stb. Közülük a facilitátort és a mentort emeljük ki.

A facilitátor (könnyítő, kifejlesztést segítő) kongruens (hiteles) személyisége hatásával, szuggesztivitásával és motiváló tehetségével is segít, empátiája és intuíciója magas szintü, akceptáló képessége erös.

A mentor (idősebb tanácsadó, nevelő, pártfogó) idősebb jóbarátként támogatja a tanuló személyiségének fejlődését, segíti egyéni életútját, karrierjét. A mentor-programok időterv és fejlödési terv szerint folynak, a mentorált aktív közremüködésével. A mentorok erös proszociális (segítő) személyiségjegyekkel rendelkeznek.

A tehetséges gyerekek tanárainak speciális ismeretekkel, meghatározott domináns személyiségjegyekkel, készségekkel kell rendelkezniük. Fokozódik az olyan tulajdonságok fontossága, mint

- az alternatíva-állítás,

- a szerep feletti uralom képessége,

- az új technikák befogadás,

- az információ befogadása és -feldolgozás,

- a tanulni tudni stb. tanítása.

A személyiségvonások között újak is megjelennek, vagy a meglévők dominánssá válnak, mint például:

- a vezérlés, a differenciált bánás technikái,

- a támogatási, kiigazítási, „lezárási” módszerek használatára való képesség.

Ide tartozna:

- a reális önismereti és kongruens önkifejezési képesség,

- a pozitív terepet felkutatni, megépíteni, felkarolni és fenntartani képes készségek,

- a diagnosztikus, prognosztikus képesség,

- valamint a haladási pálya differenciált vezérlése az optimumig,

- a belső energiakezelés,

- a tehetségtudat reális szinten tartása,

- az „eshetőség” kezelése,

- a tréning, fejlesztés szervezése, irányítása, képessége,

- a fejlesztő tréneri jártasság.

A tehetségtanár feladata világra hozni a tehetségeket, s az individuum aktív közremüködését lehetővé tevő kedvező lelki klímahangulat folyamatos biztosításával - megtanítani a tehetséggel gazdálkodni tudást. S mindehhez óriási tőke a tanár számára - a munkaeszközként 
KÜLÖNLEGES BÁNÁSMÓD, I. ÉVF. 2015/4.

funkcionáló, minta- és viselkedéstanító - saját személyisége. A tanár - együttmüködésre motiválva - akkor éri el a személyiségek (itt tanulók) optimális aktivációját, ha elsősorban orientál - befolyási törekvések nélkül.

\section{A tehetségfejlesztő pedagógus szerepei}

Szociálpszichológusok rengeteget használják a „szerep” fogalmát. Minden ember szerepek egész sorával rendelkezik, a családban betöltött szerepektől kezdve a munkahelyeken át egészen a nagyobb közösség szempontjából relevánsakig. A szerep ebben az értelemben tulajdonképpen beszédmódunk, öltözködésünk, viselkedésünk konzisztens mintázata, melyet a környező társas ingerekre adott reakcióként produkálunk. Így a családban vagy egy kisebb közösségben játszhatjuk például a „,bohóc”, a „gyakorlatias” vagy az „együtt érző” szerepét. A foglalkozások többnyire speciális szerep-elvárásokat tartalmaznak, így más pszichológiai követelményekkel szembesülnek a tanárok, másokkal a menedzserek és megint másokkal a munkások. Normális körülmények között meglepőnek találunk egy hangoskodó papot, egy érzékeny katonát vagy egy félénk színészt.

A társadalom ezen kívül igen kiterjedt „utasításokkal” lát el minket, mint nemi, életkori, stb. szerepek hordozóit. Ez nem jelenti azt, hogy viselkedésünk minden egyes mozzanata forgatókönyv-szerủen elö van írva számunkra, de bizonyos határok között igazodnunk kell a társadalmi elvárásokhoz. Ezek a szerepek gyakran konfliktusba kerülnek egyéni hajlamainkkal, és a személyiség érettségének egyik jele lehet, ha akár a társadalmi elvárások ellenére igyekszik „,valódi önmagát” kifejezni.

A szerep nem valamiféle, a kultúra által kidolgozott „ruhadarab”, amit csak magunkra kell öltenünk a megfelelő szituációkban, hanem egy állandóan alakuló viszonyítási folyamat eredménye, melynek során viselkedésünket ahhoz a képhez viszonyítjuk, amilyennek interakciós partnereink rólunk (illetve viselkedésünkről) kialakított elképzelését gondoljuk.

A pedagógusnak sajátos szerepkészlete van, amelyben az 1990-es évektől nagyfokú szerepátrendeződések, szerepbővülés, új szerepelemek (és pedagógus szakképesítések) megjelenése figyelhető meg a pedagógus szakmában. Amellett, hogy tovább élnek a korábbi szerepelemek (pl. oktató, nevelő személyiségfejlesztő, stb.) a pedagógusszerep gyors ütemben differenciálódott, kibővült, módosult. Egyre inkább előtérbe kerültek a pedagógusi szerepkészlet következő elemei: a kísérletező, a tanácsadó, a fejlesztő, a szociális társ, a (folyamatvezérlő) oktatástechnológus, s felerősödött a mentori, animátori, facilitátori szerep. Ez utóbbi mellett a tehetségfejlesztő pedagógusok szerepei között dominánssá vált a karriervezérlő (diagnosztizáló - prognosztizáló - felzárkóztató - fejlesztő) szerep, továbbá a támogató pszichológiai légkört teremtő képessége és folyamatos rutinja, a gazdagító programok vezérlője, az alkotásra ösztönző referencia személy mivolt. Külön jelentőséggel bír a mintaközvetítő, s a mintakövetésre késztető motiváló belső és külső marketingkezelő szerep. A belső marketing eredménye a kiegyensúlyozott, nagy énerővel rendelkező, egységes személyiségstílusú tanár, s mindezek megjelenése a biztonság sugárzásában, a hatékonyságban, s a mintaadó önérvényesítésben. A külső marketing pedig eszköztár ismereti és alkalmazkodási biztonságban, hiteles személyiségfejlesztésben, sikeres kapcsolatteremtési jártasságban egyenletes szuggesztív hatásban jelenik meg.

Különösen átfogó a szerepe a tehetségfejlesztő pedagógusnak a tanulók alkotásra való orientálásban, a hajtóerők megtalálásában és feltöltésében, $\mathrm{s}$ a saját alkotásra való beállítódásának mintaként való közvetítésében. 
A tehetségfejlesztő pedagógus személyiségében megkívánt különös tulajdonságok biztosítják a sajátos szerepek jó ellátását. Ismétlésként a következők: facilitátor, mentor, animátor, lelkész, sámán, kockáztató, akceptátor, kihíváskezelő, empátiabüvész, értéktudatosító, önkifejezésgazdagító, devianciatoló, diagnoszta, prognosztizáló, a kifejlődést segítő.

Mindezek mellett a pedagógus személyisége automatikus szerepet is ellát, egyéni pedagógus hitelességével is hat (életvitel, alkotás, eshetöség, referenciaszemély mivolt kezelése, bioszociális hatás, pszichoszociális hatás, modell hatás, a szituáció és az elvárás hatása („,Von Osten lova").

Meg kell említeni még a tehetségfejlesztő pedagógus speciális szerepei között az értékelő (kiválasztó, karrier-vezérlő, az optimumig tartó folyamatvezérlő fejlődést minősítő stb.) szerep együttest is. Mindezeken túl jól kell ismernie a vezérlés és differenciált hatás technikáit, rutinszerüen használni a támogatási - kiigazítási - lezárási módszereket, a felkutatás felkarolás mechanizmusait (sas-szem effektus) az energiakezelés, a tehetségtudat reális szinten tartása, s az eshetőség kezelése módjait. S ugyanakkor biztonsággal dolgozó csoporttechnikusnak, trénernek is kell lennie.

\section{Hogyan fejlesszünk? A pedagógusok személyiségének felmérése és fejlesztése}

Diagnózis. A pedagógusok személyiségét - felmérés, diagnózis nyomán - korszerü csoporttechnikákkal alakítjuk elsősorban azzal a céllal, hogy - személyiségük erejére, belső tőkéjükre támaszkodva - a diákok körében hatékony felmérést és személyiségfejlesztést végezhessenek.

A fejlesztés minden lépcsőjét szükségszerüen megelőző diagnózis kiterjed az általános és a speciális jellemzők mérésére egyaránt. Mi itt csak azokat a területeket vettük figyelembe, azon vizsgálandó szeleteket emeljük ki, amelyek elengedhetetlenül fontosak a fiatalokkal foglalkozó felnőttek lelki stabilitásának megteremtésében. A pedagógus személyiségének azon területeit igyekszünk itt megragadni, amelyek különös szerepet játszanak a személyiségfejlesztő munka hatékonyságában. A vizsgálandó területek a következők:

a) A pedagóguspálya motivációs háttere.

A pályaválasztási indítékok jellegének és erősségének feltérképezését tüzzük ki célul.

b) A munkával kapcsolatos igények vizsgálata.

A végzendő munkához kapcsolódó igények lényegesen befolyásolják a humán erőforrások müködésbe lépését, ezért vesszük szemügyre ezek sajátosságait, fejlődését is.

c) Az önelfogadás mértékének mérése.

A személyiség harmonikus müködésének feltétele, hogy az egyén fogadja el önmagát, az ebben tapasztalható zavarok is kihatnak az erőforrások nem hatékony müködésére.

d) Az én-erő vizsgálata. Az emberi erőforrások mozgásba lendülésének egyik fokmérője az én-erő.

e) Facilitátori jellemzők: összehangolt önismeret, önreflexiós készségek, akceptálási (önelfogadás és mások elfogadása) képesség, empátiás hajlam és készség, adekvát önkifejezés, egyéni hatástudat, sikeres én-dinamika és én-marketing, kongruencia (hiteles személyiség), pályakívánás és pályaelégedettség, kompatibilitás (valóságkezeléshez, mintaadáshoz, személyiség karrier-készségek átadásához), reflexív, diagnosztizáló és prognosztizáló készségek, innováció, stressz és konfliktus felismerés, -kezelés és -hasznosítás, distressz-türés, egyéni pedagógusi hitelesség (életvitel, 
KÜLÖNLEGES BÁNÁSMÓD, I. ÉVF. 2015/4.

jövőtervezés, alkotás, eshetőség és referencia személy mivolt kezelése), személyiség-, fittség és komfortérzet. Ezek megléte szükséges a sikeres facilitátori - fejlesztő tanári munkához.

Fejlesztés. A tehetségfejlesztő tanárok - speciális szerepükre való - felkészítő kurzusain (elmélet munícióra építve) egymás mellett szükséges fejleszteni a pedagógus személyiségét (reális önismeret, önértékelés, adekvát önkifejezés, reális hatástudat, énerő, kreativitás, energiagazdálkodás, kockázatvállalás, bánni tudás nehéz emberekkel, stb.) és jártasságot adni a pedagógus-tanuló közötti hatékony kommunikációhoz, illetve a tanulók személyisége felmérését és fejlesztését segítő technikák alkalmazása terén.

Sajátos szerepet követel a pedagógustól a kreativitásból eredő sajátosságok, kísérőjelenségek feltérképezése és kezelése is; ezek közül csak a deviancia kezelését emeljük ki. Fontos szerepelem az is, hogy fel kell készülni az egyoldalú tehetségfejlesztés elkerülésére. Ezért nagyon fontos a teljes személyiség folyamatos felmérését és fejlesztését biztosító technikák készségszintü jelenléte a pedagógus eszközrendszerében.

A pedagógus személyisége munkaeszköz. Ennek értő használatához az alábbi kérdések mentén lehet eljutni:

- Ismeri-e önmagát, önkifejezését, kommunikációs eszközrendszerét, másokra gyakorolt hatását?

- Ismeri-e az önpercepciós, a tesztelési technikákat, a csoporttükrök létrehozásának és a konstruált tükrök (pl. videó) felállításának módjait, s a komplex hatásgyakorlatok alkalmazását?

$\mathrm{Az}$ alap önismereti és visszajelzési technikákat azért kell készséggé tenni, hogy a pedagógusok azokat (minta és viselkedéstanítóként) a tanulóknak át tudják adni.

A tesztek provokálásra, önbevallásra, mérésre, tulajdonságok tesztben való kifejeződésére történő alkalmazását pedig azért kell megtanulni, mivel folyamatosan szükség van a tanulók személyiségének ismeretére (személyiség-térképkészítés, diagnózis) és a személyiség-fejlesztésre (a tehetségterület sikeréhez leginkább szükséges személyiségjegyek dominánssá tételére).

\section{Korszerü pedagógiai-pszichológiai technikák a tehetségfejlesztő pedagógus önismereti és fejlesztő munkájához}

A tehetségfejlesztő pedagógusok speciális szerepekre való felkészítésében elsősorban az énerőnövekedést, a kreativitás fejlesztését, a kedvező lelki klíma kialakítását segítő, s a hatékony pedagógus-tanuló kommunikációt megalapozó önismereti kommunikációt fejlesztő csoportok fejlesztő hatását kell kihasználni.

E hatás a következőkben nyilvánul meg:

- az interperszonális feed-back fejlesztése,

- az empátiás készségek javítása,

- az önkritika növelése,

- a szerepcserék és decentrálás átélése, az interperszonális rizikó-vállalás növelése a sikeres kommunikáció érdekében,

- a készségek beágyazódása, bevésődése, belsővé válása, automatizáslás, technikalitás a viselkedésben,

- kapcsolatépítési készségek (bizalomkeltés, együttmüködés, siker és kudarckezelés) fejlödése. 
KÜLÖNLEGES BÁNÁSMÓD, I. ÉVF. 2015/4.

A személyiségfejlesztéshez a pedagógus először önmagát teszi rendbe (belső marketing), ezzel kifelé irányítható energiát kap (külső marketing).

A kiegyensúlyozottnak ható személyiség egyik nagyon fontos tőkéje a nagy énerö. Ez reális önismereten és önértékelésen alapul, s önmenedzselési jártasság is szükséges hozzá. A személyiség kiegyensúlyozottsága szempontjából az énképpel és testképpel való elégedettségnek erős kifejlődése szükséges (ötfokú skála esetén 3,75 - 4,5 között).

Az énkép több, mint a saját tulajdonságok ismerete, azoknak az „értékelése” is hozzátartozik önérzet, önbecsülés formájában, s egyes személyiségstílust, viselkedés mozzanatokat is jelent.

$\mathrm{Az}$ önmagát elfogadni tudó embert a következők jellemzik (ezek témánk szempontjából nagyon fontosak):

- belső kontroll,

- megfelelö önbizalom,

- felelősségteljesség,

- kritika elfogadása,

- képes ellenállni a külső nyomásnak.

Az énerős személyiség

- tud szándékai és céljai szerint viselkedni,

- képes belső feszültségét kontrollálni, szabályozni.

A fejlesztő pedagógus vezető/vezérlő funkciója eredményes gyakorlásának feltétele a fejlett énerő, amely az önmagában való biztonságot, a határozottságot, a szorongásmentességet és a mintaadó önérvényesítést adja.

Az énképben és a testképben az önmagunkra vonatkozó emlékek sokasága jelenik meg, ezek az önmagunkkal szembeni elöítéletek csökkentése és a személyes értékesség tudata, biztonságtudat erősítése érdekében feltárhatók, fejleszthetők.

Énképünk három lényeges eleme: a befogadottság, az értékesség, és az alkalmasság érzése kölcsönhatással vannak egymással, s az önmagunkkal való elégedettség szintjével mérhetök.

Nagyon lényeges a pedagógus és a tanuló közötti érzelmi biztonság. Ennek megteremtéséhez fontosak az érzelmi biztonságtudatot erősítő képességek (empátia, azonosság, szeretet stb.) erősítése, fejlesztése, ill. érzelmi biztonság hiányát erősítő reakciók (pl. az ellenségesség, a büntudat, a félelem, elfojtás stb.) felfedezése, gyengítése, „elaltatása”.

A tanulók megismerésének nélkülözhetetlen eleme a gyerek és fiatal önmagához való viszonyát megmutató vonások (pl. önbizalom, önbecsülés, elbizakodottság, büszkeség, egoizmus, szerénység, becsvágy, bátortalanság stb.) feltérképezése.

A tehetségfejlesztő pedagógus szerepéhez tartozik a tanulók következő jellemzőinek mély megismerése is: érettség, akaraterö, teljesítmény, rangsortudat, sajátos személyiségvonások, érdeklődés, fizikai állapot, elégedettség, fontosságtudat, perspektívaérzet, energiagazdálkodás tudatossági szintje, beállítódás, a speciális érdeklődés mélysége, munkaerkölcs, őszinteség, önuralom, kitartás, intelligencia (eredetiség, képzelet, memória, önállóság, ítélőképesség, kombinálóképesség, realitásérzék), emocionális érzékenység stb.

A tehetségfejlesztő pedagógus nem pazarolhat belül, nem teljesíthet lehetőségei alatt (még ha ez nálunk csaknem általános jelenség is). Pontosan ismernie kell személyiség-eszköztárát, s pontosan tudnia kell azt, hogy mi teszi mindig hitelessé személyiségközlését. Ugyancsak komoly pedagógiai tőke a kapcsolatépítési jártasság, a bizalomkeltéshez és fenntartáshoz 
szükséges szuggesztív (másokra) hatás. Elengedhetetlen az együttmüködés koordinálása, a sikerek és kudarcok kezelése, valamint a felismerési, kezelési és elviselési technikák magas szintje.

A tehetségpedagógus státus tudati állapot is. Ez jelenti a kényszerpályák megértését és tudatos vállalását, (a) kudarctürő képesség (frusztrációs tolerancia) erős voltát a hajtóenergiák megtalálásának és feltöltésének, valamint a kedvezö lelki klímahangulat kialakításának képességét. Jelen van náluk a fejlödésorientált gondolkodás (b), a hajtó erők müködésének megértésének megértése és kézben tartása (c).

A tehetségfejlesztő pedagógus átfogó szerepe a tanítványok alkotásra orientálása. Ehhez speciális tanári szemléletnek kell kialakulnia, amely (mintát adó) alkotásra való beállítódást eredményez, s feltétele alkotó-innovatív légkör megteremtésének. A tehetségfelméréshez, fejlődéshez, s a személyiségalakításhoz elengedhetetlen az egyéni és csoportos alkotási technikák elsajátítása és a tanulóknak való átadás, kifejlesztés képességének a kialakulása.

\section{A facilitátor (tehetségfejlesztő) pedagógus személyiségének felmérése és fejlesztése}

Bevezetésül nézzük meg, fejleszthető-e a segítő (pedagógus) személyisége? Egyértelmü a különböző felfogásokból az, hogy a személyiség pszichológiai szerveződése alakítható, képlékeny, rugalmas és állandó változásra, nagyfokú alkalmazkodásra képes - a külső (környezeti) és a belső (öröklött és szerzett) hatások függvényében.

A személyiség magába foglalja az ember lelki életének azon jellegzetességeit, tulajdonságait, megnyilvánulásait, amelyek, egyértelmüen megkülönböztetik őt másoktól, vagyis meghatározzák az egyén személyes stílusát és befolyásolják a környezetével való kapcsolatát.

S milyen a segítő ember, a fejlesztőtanár, a facilitátor személyisége?

Egy hazai kutatás (Galambos, 1991) hat fö tulajdonságcsoport meglétét és magas értékét tartja elvárhatónak a humán pályán dolgozóktól. Ezek a következők:

- Általános és szakmai intelligencia, kompetencia,

- Személyes irányultság, önbizalom,

- Másokra irányulás, szociabilitás,

- Emocionális stabilitás, én-erősség,

- Erkölcsiség, altruizmus (erős superego),

- Gyakorlatiasság (praxernia).

A következőkben két mérési lehetőséget vázolunk fel dióhéjban. A segítő pályára való kiválasztásnál alapmódszer a személyiségtérképkészítés (diagnózis) és a pedagógusi - emberi perspektíva-tervezés. A komplex személyiségtérkép elkésztéséhez mérni kell pl. a sajátos iránti attitüdöt a proszociális jellemzők erősségét, az (ön és másokra vonatkozó) elöítéletességet, toleranciát, a pedagógus identitást, a kommunikációs képességeket és az interperszonális készségeket, a munkamotívumokat, az elégedettség - szintet, az alkalmasság-, a befogadottságés az értékesség érzését, az én-erőket (magabiztosság, elégedettség az én-képpel és a testképpel, önértékelés, belső igényszint és becsvágy, a sikerorientációs - kudarckerülés szintje, stb.). A személyiségtérkép-késztésre alapozható csak a fejlesztés. A pszichológiai csoportmunkával folyó fejlesztés vonatkozhat a személyes hatékonyságra, az interperszonális érzékenységre és a speciális személyiségjegyek erősítésére.

A személyiségprofil készítésében a lehető legtöbb szükséges tesztet használjuk fel. Mi itt a „Tíz teszt kihíváskezelő készségek fejlesztésére” (Külker. Főisk. 1992) eszközre építettük a 
KÜLÖNLEGES BÁNÁSMÓD, I. ÉVF. 2015/4.

mérési lehetőség bemutatását. De ugyanígy készíthetjük el a pedagógusok speciális tulajdonságai feltérképezését is.

A személyiségprofil megrajzolása: a személyiségprofil - igaz, hogy csak tíz tesztben való kifejeződésre épített - megrajzolása tuladonképpen diagnóziskészítés. A diagnózis megmu-tatja az illető egyén önpercepcióját és önreflexióit, továbbá beállítódásait, elöítéleteit, véleményét, viselkedésmódját és irányt ad az erős(ebb) és gyengébb személyiségjegyek számbavételét is lehetővé téve térkép megrajzolásához (1. ábra).

\section{1. ábra: Diagnózislap részlete}

\section{Diagnózislap}

\begin{tabular}{|c|c|c|c|c|c|c|c|c|c|c|}
\hline \multicolumn{11}{|l|}{ Név . } \\
\hline Kifejeződés & 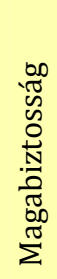 & 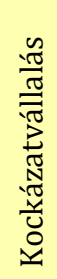 & 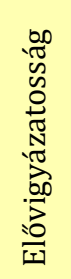 & 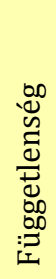 & 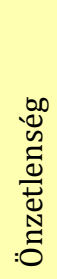 & 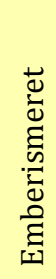 & $\begin{array}{l}\frac{\pi}{0} \\
\frac{\pi}{0} \\
\frac{\pi}{0} \\
\stackrel{0}{0}\end{array}$ & $\begin{array}{l}\frac{\pi}{0} \\
\frac{\pi}{0} \\
\frac{\tilde{0}}{0} \\
.\end{array}$ & 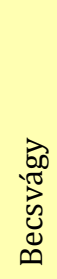 & 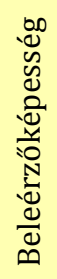 \\
\hline nagyon erős & 0 & 0 & 0 & 0 & 0 & 0 & 0 & 0 & $\mathrm{O}$ & 0 \\
\hline erös & $\mathrm{O}$ & $\mathrm{O}$ & $\mathrm{O}$ & $\mathrm{O}$ & $\mathrm{O}$ & $\mathrm{O}$ & $\mathrm{O}$ & 0 & $\mathrm{O}$ & $\mathrm{O}$ \\
\hline átlagos (közelít az erőshöz) & 0 & 0 & 0 & 0 & 0 & 0 & 0 & 0 & 0 & 0 \\
\hline átlagos (közelít a gyengébbhez) & $\mathrm{O}$ & $\mathrm{O}$ & $\mathrm{O}$ & $\mathrm{O}$ & $\mathrm{O}$ & $\mathrm{O}$ & $\mathrm{O}$ & 0 & $\mathrm{O}$ & 0 \\
\hline gyengébb & 0 & 0 & 0 & 0 & 0 & 0 & 0 & 0 & 0 & 0 \\
\hline
\end{tabular}

A (diagnózislapra) rajzolt személyiségprofil lehetőséget ad az adott személyiség jobb megismerésére és reakciói mélyebb megértésére. Ugyanakkor ez a felmérés alkalmat ad arra is, hogy a teszt kitöltését vállaló személy össze tudja vetni önpercepcióját, azt, amit gondol adott személyiségjegyeiröl, és azok tesztben való kifejeződését. $\mathrm{S}$ - ha mindez csoportos gyakorlatok közben - összehasonlíthatóvá válik a csoport által tükrözött jelzésekkel, akkor így a felmérés a reálisabb önismereti szint kialakulását is segíti.

A felmérést végző - erre kiképzett - személy számára az adott személyiségprofil jelzi a kihívások kezeléséhez, a kiegyensúlyozott életvitelhez szükséges személyiségjellemzők szintjét és állapotát.

Ezek után nézzük meg azt, hogy hogyan rajzolhatunk személyiségprofilt!

A javasolt szempontok szerint töltsük és töltessük ki a tíz tesztet! Az a jó megoldás, ha - Dr. Ranschburg Jenő javaslatát figyelembe véve - a teszteket tetszés szerinti sorrendben töltetjük ki, anélkül, hogy a kitöltő személy tudná azt, hogy milyen személyiségvonás vizsgálata következik. Ezután értékeljük a teszteket. 
Végezetül röviden tekintsük át a facilitátor domináns jegyeit, az alkalmazható mérőeszközök jelzésével:

1. A pályakívánás és elégedettség magas foka Tesztek: Motivációs teszt; A munkával kapcsolatos igények;

2. Összehangolt önismeret Tesztek: BRÉK-próba; Önértékelés-teszt; Extroverzió-introverzió 1.- 2. kérdőíve;

3. Empátiás hajlam Tesztek: Deutsh-Madle-féle kérdöív;

4. Kongruencia (C-H-Q) Tesztek: Montágh-Koncz-féle hitelesség-rács; Személyiség-profil térkép teszt;

5. A szociális kívánalmaknak való megfelelés tükörvisszajelzésekkel Tesztek. Én-dinamika térkép; Interperszonális készségteszt;

6. Stressz- és konfliktuskezelés Tesztek: Magatartás stressz-helyzetben; A kivédhetetlen stressz megküzdési stratégiái (Mentor, 2008/4 38-39. old.)

7. Akceptálás

Tesztek: Meg nem felelés érzése; Emberismeret-teszt; Egyszerü személyiség-vizsgálás;

8. Gyermekismereti kompetencia Dr. Tóth László írásai alapján

9. Reflexió és diagnosztizáló képességek Tesztek: Az önelfogadás kérdőív; Én-erő teszt; Kommunikációs képességek és stílus tesztek; Emberismeret-teszt;

10. Fittség és komfortérzet Tesztek: Fittség-teszt; Személyi-marketing teszt;

11. Önkarbantartó-, energiakezelő képesség

Tesztek: Kiégés-kezelési teszt, (Mentor, 2008/5-6. 40-41. old.); A legnagyobb erő; (a Pásztorfi-féle önszuggesztió)

Mérőeszközök a jelzetteken kívül:

- Daróczi S. és Koncz I.: Szociopedagógiai analízis I-II (2002);

- Mérei F. és Szakács F.: Pszichodiagnosztikai vademecum (1992);

- Koncz I. és Ranschburg J. : Sarokpontok (MTA Pszichológiai Intézete; (1998) kötetekben találhatók meg.

\section{Irodalom}

Balogh L. és Koncz I. (1998): A pedagógusok kiválasztása, személyiségük fejlesztése. Brüsszel. Balogh L. és Koncz I. (2008): Kiterjesztett tehetséggondozás. PEME, Budapest.

Balogh László, Bóta Margit, Dávid Imre (1999): Tehetséges tanulók - pedagógusok - iskolai fejlesztés. In Balogh László (szerk.): Tehetség és iskola. Kossuth Lajos Tudományegyetem, Debrecen. 9-51.

Bishop, W. E. (1975): Characteristics of teachers judged successful by intellectually gifted, high achieving high school students. In: Dennis, W. D. (Ed.): The intellectually gifted. New York: Grune \& Stratton.

Biddle, B.J. (1987): Teacher Roles. Oxford: Pergamon Press. 
Cropley, A. és McLeod, J. (1986): Preparing Teachers of The Gifted. International Review of Education, June 1986, Volume 32, Issue 2, pp 125-136.

Daróczi S. és Koncz I. (2002): Szociopedagógiai analízis és fejlesztö technikák I-II. BDF, Szombathely, BDF.

Feldhusen, J. F. (1984): The pursuit of excellence in gifted education. In: Feldhusen, J. F. (Ed.): Toward Excellence in Gifted Education (pp. 1-16). Denver, Col: Love.

Fontana, D. (1991): Psychology for Teachers (Ford. Koncz András, 1998) London: Macmillan Education UK

Goldhaber, D. D., and Brewer, D. J. (2000). Does teacher certification matter? High school teacher certification status and student achievement. Education Evaluation and Policy Analysis 22: 129-45.

Gustafsson, J. (2003). What do we know about the effects of school resources on educational results? Swedish Economic Policy Review, 2003 (10), 77-110.

Hultgren, H. M. és Seeley, K. R. (1982): Training teachers of the gifted: A research monograph on teacher competencies. Denver: University of Denver School of Education.

Koncz I. és Ranschburg J. (1993): Kihívások és alternatívák a kamaszkorban. MTA Pszichológiai Intézete, Budapest.

Koncz I. (1999): A pedagógus szerepe a tehetségfejlesztésben. DE, Debrecen.

Koncz I. (2002): A pedagógusi-pedagógiai kompetencia. BDF, Szombathely.

Koncz I. (2005): Kamaszkapaszkodó. Urbis Kiadó, Budapest.

Koncz I. (2006): A pedagógusszerep In Balogh L.: Pedagógiai pszichológia az iskolai gyakorlatban. Urbis Kiadó, Budapest. 247-308.

Koncz I. és Kovács J. (2011): Önismereti sarokpontok. Fapados könyvkiadó, Budapest.

Maker, C. J. (1975): Training teachers for the gifted and talented: A comparison of models. reston, VA: Eric Clearinghouse on Handicapped and Gifted Children, Council for exceptional Children.

Monk, D. H. (1994). Subject area preparation of secondary mathematics and science teachers and student achievement. Economics of Education Review, 13, 125-145.

Mönks, F. J. és Knoers, A.M.P. (2004): Fejlödéslélektan. Urbis könyvkiadó, Budapest.

Mulhern, J. D. és Ward, M. (1983): A collaborative program for developing teachers of gifted and talented students. Gifted Child Quarterly, 27, 152-156.

Ranschburg J. (2013): A serdülőkor. Saxum Kiadó Kft., Budapest.

Ranschburg J. és Koncz I. (1992): Tíz teszt a kihíváskezelö készségek fejlesztésére. Külker. Főisk., Budapest.

Rosenshine, B. (1971): Teaching behaviours and student achievement. London, England: National Foundation for Educational Research.

Ryans, D.G. (1960): Characteristics of Teachers. Washington: American Council on Education.

Silverman, R. E. (1982): Psychology. New York: Prentice-Hall.

Sisk, D. (1975). Teaching the gifted and talented teachers: A training model. Gifted Child Quarterly, 19, 81-88

Teacher Matter: Attracting Reveloping and Retaining Effective Teachers, OECD (2005)

Tóth László (2000): Pszichológia a tanításban. Pedellus Tankönyvkiadó, Debrecen.

Wilson, S., Floden, R.E. és Ferrini-Mundy, J. (2001): Teacher Preparation Research: Current Knowledge, Gaps, and Recommendations. Washington: University of Washington. 